\title{
Soil Quality Analysis for Sustainability of Forest Ecosystem: The Case of Chilimo-Gaji Forest, West Shewa Zone, Ethiopia
}

\author{
Siraj Mammo ${ }^{1,2}$ Zhang Kebin ${ }^{1}$ Achalu Chimidi ${ }^{3} \quad$ Hamza Ibrahim $^{3}$ \\ 1.Beijing Forestry University, School of Soil and Water Conservation \\ 2.Department of Biology, College of Natural and Computational Sciences, Ambo University \\ 3.Department of Natural Resource Management, College of Agriculture and Veterinary Sciences, Ambo \\ University
}

\begin{abstract}
The study was conducted to assess the soil quality with respect to the sustainability of Chilimo-Gaji Forest ecosystem using selected soils physicochemical parameters. Soil samples were taken through random sampling from the natural forest land under three different forest user groups (FUGs) in order to determine selected soils physicochemical properties. The result of the present study indicated that total $\mathrm{N}$, available $\mathrm{P}$ and $\mathrm{K}$, and $\% \mathrm{C}$ were higher on the surface soil $(0-20 \mathrm{~cm})$ than in the subsoil $(20-30 \mathrm{~cm})$ depth indicating more nutrients are concentrated in the surface soil. The result of the study also revealed that presence of low bulk density ranges from 0.4 to 1.029 and high moisture content of soil ranging $4.89 \%-7.60 \%$. The result also indicated that there is a higher per cent of carbon and organic matter across the three FUGs with Galessa recording the highest \% carbon (7.69) and organic matter (13.25), followed by Gaji and Chilimo FUGs. The study also revealed that forest soil of the study area was very fertile and sustainable as the parameters analyzed indicating the forest ecosystem in the study area is sustainably managed under the new paradigm of participatory forest management. Scaling up participatory forest management to other protected forests in Ethiopia is crucial and plays a key role in the sustainability of healthy forest ecosystem.
\end{abstract}

Keywords: Ethiopia; Forest user groups; physicochemical parameters; Soil organic carbon; Soil quality

DOI: $10.7176 / \mathrm{JEES} / 9-3-01$

Publication date:March $31^{\text {st }} 2019$

\section{Introduction}

According to Doran, (1997), soil health is defined as the continued ability of soil to function as a vital living system, within ecosystem and land-use boundaries; promote the quality of air and water environments; to sustain biological productivity; and maintain plant, animal, and human health. Soil quality degradation is one of the evident result of the increased pressure on land resources (MEA, 2005, De Laurentiis et al, 2019) associated with the intensification and expansion of human activities for different purposes. The maintenance of soil quality is critical to environmental sustainability (Arshad \& Martin, 2002). Currently, assessing soil properties has gained a worldwide attention in determining the effect of management practices on the quality of soil relative to the sustainability of forest ecosystem functions in addition to plant productivity (Schoenholtz et al, 2000). Soil provides key ecosystem services benefits to a human beings such as water, food, timber, and fiber; regulating services that affect climate, floods, disease, waste and water quality; cultural services that deliver recreational, aesthetic and spiritual benefits; and supporting services such as nutrient cycling (MEA, 2005; Evans et al, 2016).

The soil carbon is the largest component of the global carbon cycle and its management can significantly impact the concentration of atmospheric $\mathrm{CO}_{2}$ (Murty et al, 2002). Its carbon pool is the largest of the terrestrial pools as it comprises three times more carbon than in atmosphere and 3.8 times more carbon than in living pool (Lal and Kimble, 1997). The existence of the strong relationship between soil organic matter (SOM) and forest productivity has important implications for forest sustainability (Grigal\& Vance, 2000) and the important management concern is the extent of soil carbon released into the atmosphere when forest land is converted into agricultural land. SOC plays a significant role in alleviating the impacts of greenhouse gases and storing, maintaining clean water and reducing $\mathrm{CO}_{2}$ in the atmosphere, enhancing soil quality, sustaining and improving food production (Sakin, 2012). Today, climate change is becoming a worldwide agenda due to increasing amount of greenhouse gases as carbon dioxide is a major gas in the atmosphere, this could be mitigated by sequestering carbon into vegetative cover and soil (Nair et al, 2015). Restoration of degraded soils and adoption of improved management practices of agricultural and forestry soils are the most important strategies of soil C sequestration

The term soil quality and soil health are becoming increasingly interchangeably used worldwide and defined as the ability of a soil to function within its ecosystem borders and intermingle positively with the environment external to that ecosystem (Larson and Pierce, 1991). A soil quality indicator is a simple feature of the soil which may be measured to assess quality with respect to a given function (De la Rosa \& Sobral, 2008).. A modern consensus definition of soil health is the continual ability of the soil to function as a vital living ecosystem that sustains animals, plants, and humans (USDA-NRCS, 2012) such as nutrient cycling, water (infiltration \&availability), filtering and buffering, physical stability and support, habitat for biodiversity and can be assessed 
by laboratory test using a wide range of biological, chemical and physical indicators. Soil quality plays a key role in sustainable land use management and for forests to be sustainable; the capability of soil to support vegetative growth must be maintained (Page-Dumroese, 2000).

The production capacity of afforestation is highly dependent on availability of soil nutrients which is impacted by management activities and species (Binkley, 1997). Soils reply differently to management based on the inherent properties of the soil and the adjacent landscape. Generally, it is assumed that forests with diverse tree species are more productive with greater ability to sequester more $\mathrm{C}$ and improve regulating services such as water and nutrient flows, compared to less diverse forests (Aerts and Honnay, 2011, Evans et al, 2016). Suitable management practices for each land use within each geographical area are important to preserve soil functions and thus promote (Zornoza et al, 2015). The enhancement of soil quality has been reported as a common criterion when assessing long-term sustainability of forest ecosystems (Schoenholtz et al, 2000) and critical to environmental sustainability

Conserving and improving soil quality is about sustaining the long-term function of the earth plant soils. The importance of soil quality lies in achieving sustainable land use and management systems, to balance productivity and environmental protection (De la Rosa \& Sobral, 2008). The soil chemical and physical properties which are used as determinants of soil quality play relevant and crucial role in assessment and advancement of sustainable forest and management and have been reported to have the capacity to determine productivity of forests (Schoenholtz et al, 2000), in addition to biological properties that combine and contribute to soil function and used as a framework for evaluation of the soil (Rahimabady et al, 2015). Soil functions can be disrupted by several factors and human activities have a massive potential for causing soil degradation. Many of the physical properties important for assessing soils in agricultural systems are the same for forest soils (Maynard \& Curran, 2007) and can be assessed through the use of key soil physicochemical properties, or indicators, that reveal key soil processes (Craig \& Arlene, 2002).

Organic Carbon (OC) is one of the key soil quality parameters that enable the accessibility to nutrients (Rahimabady et al, 2015). The soil organic carbon has been reported both as soil quality indicator and a broader indicator of ecosystem response to environmental changes (Perie and Ouimet, 2008). The strength of the relationship between SOM and forest productivity has significant implications for forest sustainability (Grigal \& Vance, 2000). However, the most important management issue is the extent of soil carbon discharged into the atmosphere when forest land is transformed into agricultural land. Forest soil organic matter is one of the important constituent of the global carbon cycle and the changes in its storage and decomposition directly affect terrestrial ecosystem carbon storage and global carbon equilibrium (Joshi et al, 2015).

The loss of SOM component could lead to soil erosion as well as considerable loss of nutrients which may disturb overall, the functionality of the ecosystem (Pimentel \& Kounang, 1998) and sustainable utilization, management and conservation of the forest. Currently, there are international and national calls for management of forestry on a sustainable basis by consistently including maintenance or enhancement of forest soil quality as a criterion of sustainability (Schoenholtz et al, 2000). The major objectives of this study, conducted in Chilimo-Gaji forest is to determine the soil physicochemical properties which are used as determinants of soil quality as an of indicator sustainable forest management under different forest user groups.

\section{Materials and Methods}

\subsection{Description of the Study Area}

Chilimo forest is one of the few remnant native dry Afro-Montane forests on the Central Highlands of Ethiopia located in the Dendi district near to the small town of Ginchi, Western Shewa Zone, Oromia State of Ethiopia. Its geographical location is $38^{\circ} 10^{\prime} \mathrm{E}$, and $9^{\circ} 05$ ' $\mathrm{N}$ (Fig. 1). Attitudinally, the forest area ranges between 2170 to 3054 $\mathrm{m}$ a.s.l. The forest is a small enclave in the western section of the ridge that stretches from the capital westward to Gedo highlands (Soromessa \& Kelbessa, 2014). It's home to over 150 bird species, 21 mammal species and several predictive subspecies such as the Menelik's bushbuck, vervet monkey, Colobus monkey, Anubis baboon and Leopard (Woldemariam, 1998). The forest is composed of mixed broad leaved coniferous forest and characterized by the dominant tree species of Juniperus procera, Podocarpus falcatus, Prunus africanum, Olea europaea, and Hagenia abyssinica. The report from Soromessa \& Kelbessa (2014) indicated that Chilimo-Gaji forest is known with its diversity and endemism with a total of 213 different plant species categorized into 83 families, with angiosperm 193 species, pteridophytes (16 species) gymnosperms (represented by 2 exotic and 2 indigenous species); including 17 plant species that are unique to the Chilimo-Gaji forest.

Chilimo forest is categorized as one of Ethiopia's 58 national priority forest protected areas in order to minimize deforestation. Due to continuous deforestation, the Chilimo forest cover has declined from 22,000 ha in 1982 to 6000 ha in 1991 (Dugo, 2009). Currently, the forest cover area is estimated about 5,000 ha, owned by the state. Though the forest is owned by state, currently it is divided into blocks and managed by forest user groups and cooperatives under the participatory forest management (PFM arrangement schemes. The PFM in Ethiopia was introduced in the late 1990s with a major strategy for managing natural forests for sustainable use with the objective of promoting conservation of forest ecosystems with a view to improving the livelihood of people living 
in or around these resources. Due to introduction of PFM in Chilimo -Gaji forest deforestation rates have shown in declining trend between the time periods 2008-2015 (Siraj et al, 2018). The introduction of PFM has led to the formation of forest user groups (FUGs) and empowers them as owners and managers of the natural resources by allocating forest units to them to save remnants of forests reserves (Siraj et al, 2016). The FUGs take collective responsibilities for the sustainable management of the forest by signing contracts with the government (Anders, 2000; Kubsa et al, 2003).

This type of forest management in many regions is assumed to be acting to improve forest conditions and the livelihood of the FUGs. Chilimo Gaji is the pioneer of PFM site in Ethiopia, where the FUGs have formed a strong cooperative union. The local community around forest uses the forest for different purposes such as for grazing, firewood, as source of water, and construction materials (Siraj et al, 2018). PFM focuses on improving the livelihood and conserving natural forest systems through local participation and cooperation and can deliver multiple outcomes such as carbon storage, livelihood benefits and biodiversity conservation (Agrawal \& Angelsen, 2009) and can lead to sustainable use of forest resources (Siraj \& Zhang 2018).

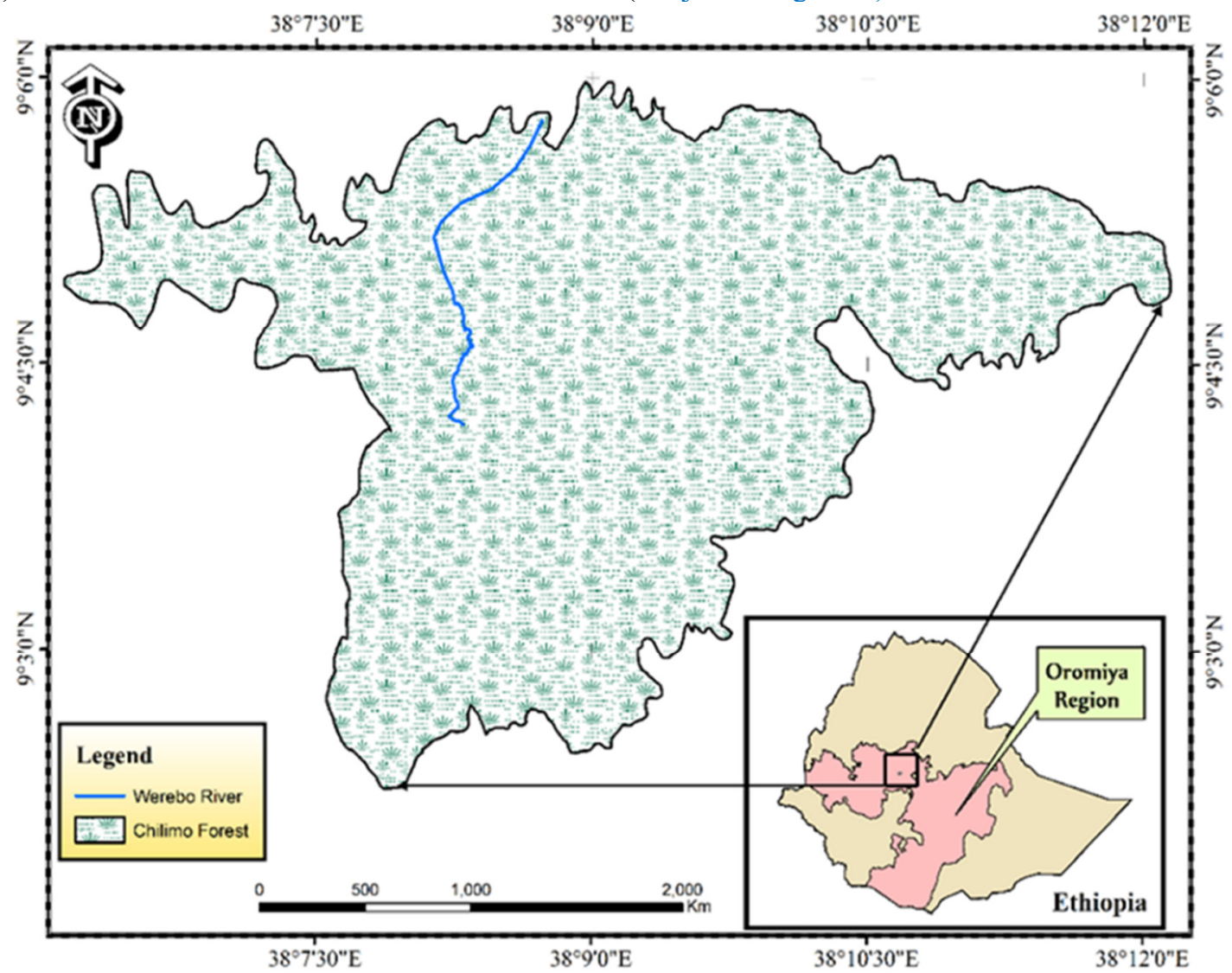

Figure. 1. Location map of the study area

\subsection{Climate}

The Chilimo Gaji forest area and the surrounding peasant associations are made up of two major agroecologies, namely: (i) Dega temperate like climate which is characterized by cold temperature, (ii) the Weyina Dega which is warm compared to Dega. The type and range of crops grown in these two agro-ecological zones are different and in most cases the agronomic practices are not the same. Because of cold temperature in the Dega zone the range of crops grown and potential tree species are fewer compared to the Woina Dega agro ecological zone.

The lower precipitation in the study area is from November to January and a higher rainy season from May to September (Dugo, 2009). Köppen's typology classifies the Chilimo Gaji forest as a temperate highland climate with dry winters (Cwb, subtropical highland variety) (EMA, 1988). The climatic data for 27 years was obtained from Holleta research center and analysed. June- Augest is season when highest rainfall is rrecorded and during this time almost all variety of crops is sown from the beginning up to the end of this period, though maize is sown starting from the end of march. 


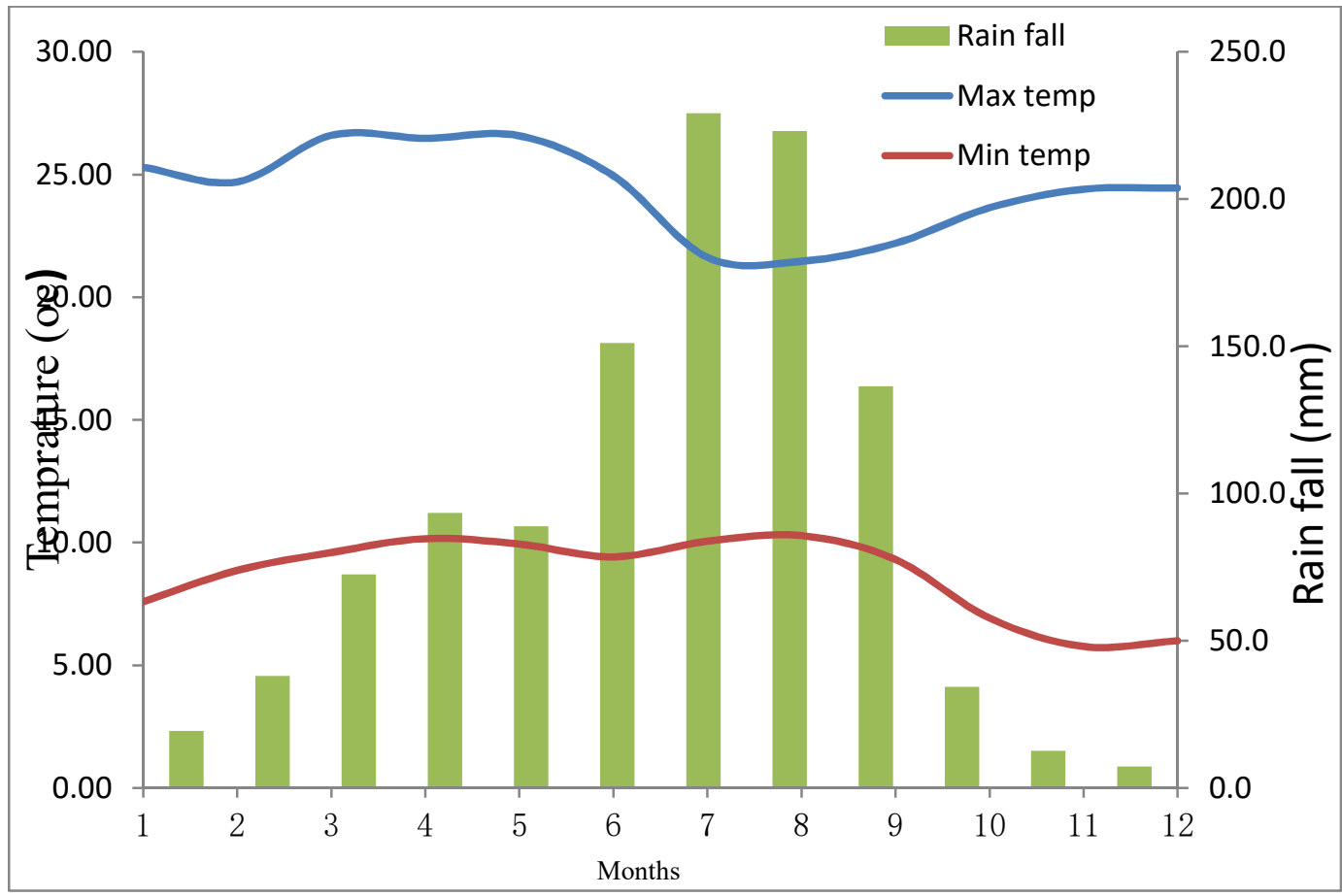

Fig 2: The1988-2014 27 years rainfall and temperature distribution of Dendi woreda

Source Holeta research center, Dendi branch (2014)

The season June-July represents one of the main cropping season of the district. From the 27 years data analysed the highest rain is recorded in the year $(2005) 1431.5 \mathrm{~mm} / \mathrm{yr}$. followed by 1996 (1410.9 mm/year). The Chilimo Gaji forest and the surrounding area receives rain for 5 months (May-September), with the highest peak is in July (Fig 2). The average yearly rainfall for the last 27 years is approximately $1091.51 \mathrm{~mm}$ in the study area (Holeta research center, 2014). The $5.31{ }^{\circ} \mathrm{C}$ was the minimum temprature recorded in 2006 , where as $25.1^{\circ} \mathrm{C}$ was the maximum temperature recorded in 2009.

\subsection{Soil Sample Collection and Laboratory Analysis}

A reconnaissance survey was carried out to identify representative soil sampling plots. Soil samples from three FUGs managed forest such as Gaji, Chilimo and Galassa were collected from $0-20 \mathrm{~cm}$ and $20-30 \mathrm{~cm}$ soil depth at eight randomly selected sites from each user group with different altitude. These two soil depths were selected to investigate the difference between the soil depths with each 3 replica, since it is commonly accepted by many studies indicating the difference between the soil depths. The representative composite soils samples were collected in a clean paper bags with the appropriate label and taken to Ambo University Chemistry Laboratory and oven dried at a temperature of $105{ }^{\circ} \mathrm{C}$ for 24 hours and then crushed to pass through a $2 \mathrm{~mm}$ mesh sieve. For the determination soil bulk density, undisturbed soil samples were collected using core sampler.

\subsection{Determination of soil quality parameters}

The soil samples were analyzed at Ambo University Chemistry laboratory following the standard and recommended laboratory procedures. The composited samples were analyzed for $\mathrm{pH}$, available P, total N, and Soil Organic Carbon(SOC), Soil bulk density was determined by the core method (Blake \& Hartge, 1986), Soil pH was measured in a 1:5 soil-water ratio using a glass electrode (H19017 Microprocessor) pH meter (McLean, 1982), total nitrogen was determined by the modified Kjeldahl digestion and distillation procedure (Bremner \& Mulvancy, 1982); Organic carbon content by the wet combustion or dichromate oxidation methods (Walkely \& Black, 1934) and SOM was determined titrimetrically; available phosphorus with modified version of Olsen's method (Olsen \& Sommer, 1982), and available potassium by the ammonia acetate method (Thomas, 1982). All the selected soil quality parameters measured were subjected to a one-way analysis of variance using the statistical package for social sciences (SPSS) and where significant difference exists means were separated using the least significant difference method.

\section{Result and Discussion}

\subsection{Bulk Density and Soil Moisture}

Bulk density is an indicator of soil compaction and soil health. It influences soil porosity, rooting depth/restrictions, infiltration, available water capacity, plant nutrient availability, and soil microorganism activity. The average mean 
bulk density values across the study site range from 0.617 for Galessa to 0.80 and 0.883 recorded for Chilimo and Gaji respectively, which can be described as low. This is expected considering the high level of SOM content of the soil. Higher soil bulk density is an indication of low organic matter viz-a-viz. Galessa specifically has recorded higher values for all the parameters measured.

Soil moisture is one of the essential key elements in the atmospheric water cycle (WMO, 1983).

Soil moisture from hydrological perspectives, controls the partitioning of rainfall into runoff and infiltration and therefore affects erosion, evapotranspiration, runoff, solute transport, and land-atmosphere interaction (Tyagi et al., 2013). The result of this study showed that moisture content ranged from $6.19 \%-7.40 \%$ (table 2). The percent moisture content across the different site was found to be high, an indication of the soil ability to hold moisture. This is also linked to the soil carbon and organic matter content, which all indicate higher levels. The presence of high vegetation soil cover, have higher soil moisture content as compared to other forests with low vegetation cover DOI:10.15680/IJIRSET.2015.0408071. A decrease in moisture per cent was observed with depth. Mineralization can never be eliminated in fertile soils, with a huge population of active microorganisms (105 to $107 \mathrm{MOs} /$ gram of soil). Mineralization is regulated by soil moisture content and soil temperature. SOM contains about $5 \% \mathrm{~N}$, when total soil $\mathrm{N}$ increases, the quantity of $\mathrm{N}$ mineralized from soil organic $\mathrm{N}$ also increases. With available optimum moisture, the process will continue without any difficulty. Therefore soil management strategies, which conserve or increase SOM, will result to a greater contribution of mineralizable $\mathrm{N}$ to $\mathrm{N}$ availability to plant species.

The soil of the Chilimo-Gaji forest as represented by the samples from the different FUGS showed that moisture content was higher in the upper soil horizon $(0-20 \mathrm{~cm})$ and decreased slightly with an increase in soil depth.

\subsection{Soil pH}

Soil $\mathrm{pH}$ is one of the important soil quality parameters used to assess the potential accessibility of beneficial nutrients and toxic elements to plants. It also influences nutrient uptake, as well as tree growth in forests. Several plants can tolerate $\mathrm{pH}$ ranges between 5.2 and 7.8, many plants grow best in mineral soils (soils with an organic matter content less than or equal to $19 \%$ ) when soil pH is between 6.0 and 7.0 (slightly acid to neutral) (Rosen et al, 2008). The result of soil quality parameters evaluated is presented in Table 1 and 2 . In the present study, the result of soil analysis across the three different FUGs showed that the soil is slight to moderately acidic with mean values ranging between 6.5-6.97. This can be due the characteristics of the vegetation, nature of the average parent material, and precipitation. The maximum $\mathrm{pH}(6.97)$ at the surface $(0-20 \mathrm{~cm})$ was recorded at Galessa with 6. 97. This value was found to decrease slightly with the increase in depth $(20-30 \mathrm{~cm})$ though not significantly (Table1). The values recorded in this study are within the range of $(\mathrm{FAO}, 2008)$ which is 6.5 and 7.5. Within this $\mathrm{pH}$ range, $\mathrm{N}$ availability, as well as the availability of other essential elements, will be at optimum levels. The $\mathrm{pH}$ of the study area indicates that the soil is slight to moderately acidic and tending towards neutral, which agrees with (Rosen $e t$ al. 2008).

Table 1. Influence of Soil depth on Soil quality indicators $(\mathrm{pH}, \% \mathrm{C}$, Organic matter $\mathrm{OM}$ and $\% \mathrm{~N})$ at Chilimo- Gaji Forest, West Shewa, Ethiopia in 2014

\begin{tabular}{|c|c|c|c|c|c|c|c|c|}
\hline \multirow{3}{*}{$\begin{array}{l}\text { FUGs } \\
\text { Name }\end{array}$} & \multirow[b]{3}{*}{ PH } & \multirow{3}{*}{$\begin{array}{l}0-20 \\
\% \mathrm{C}\end{array}$} & \multirow[b]{2}{*}{$\mathrm{cm}$} & \multirow[t]{2}{*}{ Soil } & \multicolumn{3}{|l|}{ Depth } & \multirow[b]{3}{*}{ Total $\% \mathrm{~N}$} \\
\hline & & & & & & $20-30$ & $\mathrm{~cm}$ & \\
\hline & & & $\mathrm{OM}$ & Total $\% \mathrm{~N}$ & $\mathrm{PH}$ & $\% \mathrm{C}$ & OM & \\
\hline Gaji & 6.55 & 6.08 & 10.48 & 0.75 & 5.98 & 3.88 & 6.68 & 0.62 \\
\hline Galessa & 6.97 & 7.69 & 13.25 & 1.19 & 6.69 & 5.76 & 9.42 & 0.77 \\
\hline Chilimo & 6.78 & 5.65 & 9.74 & 1.03 & 6.74 & 3.35 & 5.77 & 0.77 \\
\hline Mean & 6.77 & 6.47 & 11.16 & 0.99 & 6.47 & 4.33 & 7.29 & 0.72 \\
\hline
\end{tabular}

\subsection{Soil organic matter}

In forests, carbon is stored in different pools, including living biomass like trees, standing and dead wood, and most prominently in soil. Sequestering carbon in soils is often seen as a 'win-win' in fighting climate change. In forest ecosystems, biomass and soil carbon are stored in dynamic equilibrium with the environment (Tesfaye et al, 2016). SOM and soil organic carbon (SOC) constitute usually a small proportion of the soil, but they are the utmost key constituents of ecosystems (Sakin, 2012).

The result of the analyzed soil samples from the three FUGs showed that there is higher percent of carbon and organic matter across the three FUGs with Galessa recording the highest \% carbon (7.69) and organic matter (13.25), followed by Gaji and Chilimo FUGs (table2.). Debele (1980) has classified soils with greater than 5.20\%, $2.6-5.2 \%, 0.8-2.6 \%$ and less than $0.8 \%$ as high, medium, low and very low, respectively in their organic matter status. In this study, the \% $\mathrm{C}$ and $\mathrm{OM}$ can be categorized as being high to very high. The percent of SOC content was greater in the topsoil layer compared to the deeper layer: $6.47 \%$ compared to $4.33 \%$, respectively. The presence of high organic matter content in the study area could be credited to high level of plant residue 
decomposition. According to Charman and Roper (2007), for soil to be productive, the organic carbon content should be in the range of between 1.8-3\%, to achieve a good soil structural conditions and stability. The values recorded in this study are far above that of (Charman \& Roper, 2007), because the soil samples, in this case, are forest soils with the high level of vegetation and liters. Generally, OM content of $4 \%$ is regarded as high. Though organic matter levels are markedly affected by cultivation history, soil depth as well as soil type. Moreover, in this study both \% C and OM decreases with soil depth (Table 1). However, SOM had been reported to positively correlate to forest productivity and it can be affected by forest management (Johnson, 1992).

\subsection{Total Nitrogen (TN)}

Total nitrogen is the main nutrient used for vegetation growth and is also used as a key soil quality assessment (Ren et al., 2014). The result of the soil samples analyzed for the study area indicated that the TN amount of the forest soils at the surface $(0-20 \mathrm{~cm})$ ranged between $0.75 \%$ in Gaji and $1.19 \%$ at Galessa which is the maximum and $1.03 \%$ recorded at Chilimo, but its content decreased with soil depth $(20-30 \mathrm{~cm})$ probably due to the decrease in organic matter content (Table 1). This result is in agreement with Buol et al., (2003) who stated a decrease in N content with increase in soil depth. Landon (2014) has classified soil based on TN content as greater than $1.0 \%$ very high, $0.5-1.0 \%$ high, $0.2-0.5 \%$ medium, $0.1-0.2 \%$ low, less than $0.1 \%$ as very low. Following this classification, the soils of the Chilimo Gaji forest sites can be described as very high $(1.19 \%)$ in the case of Galessa and high for Chilimo and Gaji. N plays a key role in forest productivity, ecosystem and nutrient recycling (Knoepp \& Swank, 2002).

\subsection{Available phosphorus (P)}

Phosphorus is one of the key soil components which its availability often limit forest productivity (Gressel \& McColl, 1997, Grigal \& Vance, 2000). The study area across the three FUGs has a higher level of available Phosphorus, with the lowest value $(38.71 \mathrm{mg} / \mathrm{kg})$ recorded at Chilimo whereas the maximum available P (84.9 $\mathrm{mg} / \mathrm{kg}$ ) was recorded for Galessa followed by Gaji (Table 2). The high $\mathrm{pH}$ of the soil must have favored also the availability of $P$. The same trend of decrease in values recorded with increase in soil depth was also observed with phosphorus, with significant decrease in values at $20-30 \mathrm{~cm}$ soil depth (Table 2). The decline in phosphorus could be attributed to decrease in organic matter content with depth. Soils that are naturally high in organic matter contain considerable amounts of organic phosphorus that are mineralized (similar to organic nitrogen), and provide available phosphorus for plant growth, in addition to a favorable soil $\mathrm{pH}$ as recorded in this study. Tekalign (1991) has described and classified soils with available P less than $10 \mathrm{ppm}, 11-31 \mathrm{ppm}, 32-56 \mathrm{ppm}$ and greater than 56 ppm as low, medium, high and very high, respectively. The average mean values recorded in the study sites 57.58 $\mathrm{mg} / \mathrm{kg}$ (for soil samples taken from 0-20cm depth) and $33.93 \mathrm{mg} / \mathrm{kg}$ (for soil samples taken from 20-30 cm depth) are all far above the recommended limit.

Table 2. Influence of Soil depth on Soil Available P, K, and \% moisture at Chilimo- Gaji Forest (2014)

\begin{tabular}{lllllll}
\hline \multirow{2}{*}{ FUG Location } & \multicolumn{7}{c}{ Soil Depth } \\
\cline { 2 - 7 } & \multicolumn{2}{c}{$0-20 \mathrm{~cm}$} & \multicolumn{2}{c}{$20-30 \mathrm{~cm}$} & $\%$ \\
& Av P $(\mathrm{Mg} / \mathrm{kg})$ & Av K $(\mathrm{cmol} / \mathrm{kg})$ & )$\%$ Moisture & Av P $(\mathrm{Mg} / \mathrm{kg}$ & Av K $(\mathrm{cmol} / \mathrm{kg})$ & $\mathrm{Moisture}$ \\
\hline Gaji & 49.13 & 2.297 & 7.19 & 23.45 & 1.551 & 7.11 \\
Galessa & 84.9 & 4.02 & 7.4 & 43.95 & 2.555 & 6.02 \\
Chilimo & 38.71 & 2.325 & 6.49 & 34.38 & 1.768 & 6.19 \\
\hline Mean & 57.58 & 2.88 & 7.03 & 33.93 & 1.958 & 6.44 \\
\hline
\end{tabular}

\subsection{Available potassium (K)}

The analysis of soil sample collected across the forest user groups FUGs showed that available K, was higher in the surface soil than in the sub soil. The available K content ranged between $2.287 \mathrm{cmol} / \mathrm{kg}$ to $4.020 \mathrm{cmol} / \mathrm{kg}$ for 0 $20 \mathrm{~cm}$ soil depth and $1.551 \mathrm{cmol} / \mathrm{kg}$ to $2.555 \mathrm{cmol} / \mathrm{kg}$ for $20-30 \mathrm{~cm}$ soil depth (Table 2 ). The maximum $\mathrm{K}$ content was recorded at Galessa FUGs with both soil depths. The K content of the soil can be described as adequate, high, and very high content of available $\mathrm{K}(2.325,2.555$, and $4.020 \mathrm{cmol} / \mathrm{kg})$. K was also observed to decrease with depth. In general, the surveyed forest field soils had enough $\mathrm{K}$ in the range that supports the growth of plant species. This confirms the long existing general view that the parent materials from which most Ethiopian soils are formed was rich in potassium.

The output of ANOVA using the statistical package for social sciences (SPSS) indicated that Carbon content, organic matter and total nitrogen are stastical significantly negtively correlated to soil depth at $\mathrm{P}<0.05$. However $\mathrm{pH}$ significantly positively correlated to forest management at $\mathrm{P}<0.05$ (Table 3 ). The altitude of the study area did not seem to have shown a significant influence on the parameters measured (Table 3). All the forest user groups' fall within highland classification, Gaji and Galessa being grouped as one based on altitude and Chilimo another with an altitude difference of around 400 masl. 
Table 3.Results of one way ANOVA

\begin{tabular}{|c|c|c|c|c|c|c|}
\hline \multirow[t]{2}{*}{ Model } & & \multicolumn{2}{|c|}{ Unstandardized Coefficients } & \multirow{2}{*}{$\begin{array}{l}\text { Standardized } \\
\text { Coefficients } \\
\text { Beta }\end{array}$} & \multirow[t]{2}{*}{$\mathrm{t}$} & \multirow[t]{2}{*}{ Sig. } \\
\hline & & B & Std. Error & & & \\
\hline \multirow{4}{*}{ PH } & (Constant) & 8.048 & 1.130 & & 7.119 & .000 \\
\hline & Altitude & -.001 & .000 & -.337 & -1.658 & .123 \\
\hline & Forest management & .290 & .102 & .575 & 2.828 & .015 \\
\hline & Soil depth & -.224 & .144 & -.314 & -1.552 & .147 \\
\hline \multirow{4}{*}{ Moisture } & (Constant) & 2.935 & 2.892 & & 1.015 & .330 \\
\hline & Altitude & .002 & .001 & .377 & 1.552 & .147 \\
\hline & Forest management & -.258 & .262 & -.239 & -.984 & .344 \\
\hline & Soil depth & -.517 & .369 & -.339 & -1.403 & .186 \\
\hline \multirow{4}{*}{ Carbon } & (Constant) & -6.329 & 5.723 & & -1.106 & .290 \\
\hline & Altitude & .004 & .002 & .370 & 1.935 & .077 \\
\hline & Forest management & .779 & .518 & .288 & 1.504 & .159 \\
\hline & Soil depth & -2.183 & .730 & -.570 & -2.991 & .011 \\
\hline \multirow{4}{*}{$\mathrm{OM}$} & (Constant) & -9.846 & 10.344 & & -.952 & .360 \\
\hline & Altitude & .007 & .004 & .348 & 1.766 & .103 \\
\hline & Forest management & 1.224 & .937 & .257 & 1.307 & .216 \\
\hline & Soil depth & -3.890 & 1.319 & -.578 & -2.949 & .012 \\
\hline \multirow{4}{*}{$\mathrm{P}$} & (Constant) & -51.845 & 88.095 & & -.589 & .567 \\
\hline & Altitude & .030 & .033 & .206 & .887 & .392 \\
\hline & Forest management & 13.407 & 7.979 & .390 & 1.680 & .119 \\
\hline & Soil depth & -18.824 & 11.235 & -.387 & -1.675 & .120 \\
\hline \multirow{4}{*}{$\mathrm{N}$} & (Constant) & .556 & .973 & & .571 & .578 \\
\hline & Altitude & $5.915 \mathrm{E}-005$ & .000 & .033 & .161 & .875 \\
\hline & Forest management & .143 & .088 & .337 & 1.618 & .132 \\
\hline & Soil depth & -.363 & .124 & -.607 & -2.929 & .013 \\
\hline \multirow{4}{*}{ K } & (Constant) & -1.434 & 4.896 & & -.293 & .775 \\
\hline & Altitude & .001 & .002 & .145 & .586 & .568 \\
\hline & Forest management & .658 & .443 & .367 & 1.483 & .164 \\
\hline & Soil depth & -.831 & .624 & -.328 & -1.331 & .208 \\
\hline
\end{tabular}

\section{Conclusion and Recommendation}

This study demonstrated that natural forest land systems have good soil quality as per the parameters measured. The overall result of this study showed that total $\mathrm{N}$, available $\mathrm{P}$ and $\mathrm{K}, \% \mathrm{OM}$ and $\% \mathrm{C}$ are higher in the surface soil $(0-20 \mathrm{~cm})$ than in the sub soil $(20-30 \mathrm{~cm})$, that is to say more nutrients are concentrated in the surface soil of the study area, implying that species on this soil can have more access to nutrients within the rooting depth. This study also revealed that forest soil properties can predict the dynamic nature of soil processes and the impact of certain management practices on those processes. The soil physicochemical properties are determinants of soil quality which can play relevant and vital role in assessment and improvement of sustainable forest management and have the capacity of determining productivity of forests. The result of this study indicated that soil quality is in a good condition indicating healthy forest ecosystem. Based on the present findings of this study, it is possible to conclude that the soil of the study area is very fertile and sustainable as the parameters measured indicating the forest ecosystem is currently managed in a sustainable manner, however frequent sampling and monitoring of these parameters is suggested as soil is dynamic and practices can change with time. Scalingn up participatory forest management through the involvement of local community to other potected forests in ethiopia is a key as it plays a key role in sustinability of healthy forest ecosystem by consistently enhancing forest soil quality. Recognizing local actors with their indigenous knowledge as key forest stakeholders and promoting their inclusion in the management of forests should be ensured to improve local livelihoods and rural development without affecting forest conservation goals including its soil quality.

\section{References}

Aerts, R., \& Honnay, O. (2011). Forest restoration, biodiversity and ecosystem functioning. BioMed Cent. Ecol. $11,29$.

Agrawal, A. \& Angelsen, A. (2009). Using community forest management to achieve REDD+ goals. In A. Angelsen, ed., Realising REDD+: national strategy and policy options. Bogor, Center for International Forestry Research. 
Anders, S. (2000). Guidelines for participatory forest management planning. Addis Ababa, FARM-Africa

Arshad, M. A., \& Martin, S. (2002). Identifying critical limits for soil quality indicators in agroecosystems. .Agriculture, Ecosystems \& Environment, 88(2), 153-160.

Binkley D. (1997). Bioassays of the influence of Ecalyptus saligna and Albizia falcataria on soil nutrient supply and limitation. Forest Ecology and Management, 91(2-3): 229-234.

Blake, G. R, Hartge, K. H. (1986). Bulk density. In: A Klute (ed). Methods of Soil Analysis. ASA and SSSA. Madison, Wisconsin, USA, pp. 363-375.

Buol, S.W., R.J. Southard, R.C. Graham, and P.A. McDaniel. (2003). Soil genesis and classification. 5th ed. Iowa State Univ. Press, Ames

Burger, J. A., Gray, G., \& Scott, D. A. (2010). Using soil quality indicators for monitoring sustainable forest management.

Charman, C and Roper, M (2007). Soil Organic matter. In P. Charman, and B. Murphy (Eds). Soils, their properties and management, 3rd edition, Oxford University Press, Melbourne, 276-285pp.

Craig, A. D., \& Arlene, J. T. (2002). Soil quality field tools: Experiences of USDA-NRCS soil quality instituted. Agron J, 94, 33-38.

De la Rosa, D., \& Sobral, R. (2008). Soil quality and methods for its assessment. In Land use and soil resources (pp. 167-200). Springer Netherlands.

Debele, B. (1980). The physical criteria and their rating proposed for land evaluation in the highland region of Ethiopia. Land use planning and regulatory department, ministry of agriculture. Addis Ababa, Ethiopia.

De Laurentiis, V., Secchi, M., Bos, U., Horn, R., Laurent, A., \& Sala, S. (2019). Soil quality index: Exploring options for a comprehensive assessment of land use impacts in LCA. Journal of Cleaner Production, 215, 63-74.

Dugo, G. S. (2009). The structure and regeration status of tree and shrub species of chilimo forest-ecological sustainability Indicators for participatory forest management (PFM) in Oromia, Ethiopia.

Food and Agricultural Organization (FAO).(2008). Plant Nutrition for Food Security. A Guide for Integrated Nutrient Management. Rome, Italy.

Gressel, N., \& McColl, J. G. (1997). Phosphorus mineralization and organic matter decomposition: a critical review.Driven by nature: Plant litter quality and decomposition.

Grigal, D. F., \& Vance, E. D. (2000). Influence of soil organic matter on forest productivity. New Zealand Journal of Forestry Science, 30(1/2), 169-205.

Grigal, D. F., \& Vance, E. D. (2000). Influence of soil organic matter on forest productivity. New Zealand Journal of Forestry Science, 30(1/2), 169-205.

Johnson, D. W. (1992). Effects of forest management on soil carbon storage. Water, Air, \& Soil Pollution, 64(1), 83-120.

Joshi, G., \& Negi, G. C. S. (2015). Physico-chemical properties along soil profiles of two dominant forest types in Western Himalaya. Current Science (00113891), 109(4).

Knoepp, J. D., \& Swank, W. T. (2002). Using soil temperature and moisture to predict forest soil nitrogen mineralization. Biology and Fertility of Soils, 36(3), 177-182.

Kubsa, A., Mariame, A., Amante, G., Lipp, H. J., \& Tadesse, T. (2003, November). Wajib: an alternative forest conservation approach for Ethiopia's forests. In XII World Forestry Congress, Quebec, Canada. http://www.fao.org/docrep/ARTICLE/WFC/XII/0145-C2.HTM

Lal, R. and J.M. Kimble. 1997. Conservation tillage for carbon sequestration. Nutr. Cycl. Agroecosyst. 49:243253.

Landon, J. R. (2014). Booker tropical soil manual: a handbook for soil survey and agricultural land evaluation in the tropics and subtropics. Routledge.

Larson, W., \& Pierce, F. (1991). Conservation and enhancement of soil quality. In Evaluation for sustainable land management in the developing world: proceedings of the International Workshop on Evaluation for Sustainable Land Management in the Developing World, Chiang Rai, Thailand, 15-21 September 1991. [Bangkok, Thailand: International Board for Soil Research and Management, 1991]..

Maynard, D. G., \& Curran, M. P. (2007). Bulk density measurement in forest soils. Soil sampling and methods of analysis. 2nd edn. Boca Raton, FL: CRC Press. p, 8639.

McLean, E. O. (1982). Soil $\mathrm{pH}$ and lime requirement. Methods of soil analysis. Part 2. Chemical and microbiological properties, (methodsofsoilan2), 199-224.

Millennium Ecosystem Assessment (MEA). (2005): Ecosystems and Human Wellbeing: Synthesis, Island Press, Washington, DC.

Murty, D., Kirschbaum, M. U., Mcmurtrie, R. E., \&Mcgilvray, H. (2002). Does conversion of forest to agricultural land change soil carbon and nitrogen? A review of the literature. Global Change Biology, 8(2), 105-123.

Nair, R., Mehta, C. R., \& Sharma, S. (2015). Carbon sequestration in soils-A Review. Agricultural Reviews, 36(2), 81-99. 
Olsen SR, Sommers LE (1982) Phosphorus. In: Page AL, et al (eds), Methods of Soil Analysis, Part 2, 2nd edn, Agron Monogr 9. ASA and ASSA, Madison WI, pp 403-430

Page-Dumroese, D., Jurgensen, M., Elliot, W., Rice, T., Nesser, J., Collins, T., \& Meurisse, R. (2000). Soil quality standards and guidelines for forest sustainability in northwestern North America. Forest Ecology and Management, 138(1), 445-462.

Perie, C., \& Ouimet, R. (2008). Organic carbon, organic matter and bulk density relationships in boreal forest soils. Canadian Journal of Soil Science. 88(3), 315-325.

Pimentel, D., \& Kounang, N. (1998). Ecology of soil erosion in ecosystems. Ecosystems, 1(5), 416-426.

Rahimabady, M. S., Akbarinia, M., \& Kooch, Y. (2015). The effect of land covers on soil quality properties in the Hyrcanian regions of Iran. Journal of BioScience \& Biotechnology, 4(1).

Ren, T., Wang, J., Chen, Q., Zhang, F., \& Lu, S. (2014). The effects of manure and nitrogen fertilizer applications on soil organic carbon and nitrogen in a high-input cropping system. PloS one, 9(5), e97732.

Rosen, C. J., Bierman, P. M., \& Eliason, R. (2008). Soil test interpretations and fertilizer management for lawns, turf, gardens, and landscape plants.

Sakin, E. (2012). Organic carbon organic matter and bulk density relationships in arid-semi arid soils in Southeast Anatolia region. African Journal of Biotechnology, 11(6), 1373-1377.

Schoenholtz, S. H., Van Miegroet, H., \& Burger, J. A. (2000). A review of chemical and physical properties as indicators of forest soil quality: challenges and opportunities. Forest ecology and management, 138(1), 335356.

Siraj, M., Zhang, K., Xiao, W., Bilal, A., Gemechu, S., Geda, K.\& Xiaodan, L. (2016). Does Participatory Forest Management Save the Remnant Forest in Ethiopia?. Proceedings of the National Academy of Sciences, India Section B: Biological Sciences, 1-14.

Siraj, M., Zhang K., Moges, K.(2018): Retrospective Analysis of Land Use Land Cover Dynamics Using GIS and Remote sensing in Central Highlands of Ethiopia

Siraj, M \& Zhang, K (2018) Structure and natural regeneration of woody species at central highlands of Ethiopia

Soromessa, T., \& Kelbessa, E. (2014). Diversity and endemicity of Chilimo forest, central Ethiopia. Bioscience Discovery,4(1), 1-4.

Tekalign, T., Haque, I., \& Aduayi, E. A. (1991). Soil, plant, water, fertilizer, animal manure and compost analysis. Working document, (13).

Tesfaye, M. A., Bravo, F., Ruiz-Peinado, R., Pando, V., \& Bravo-Oviedo, A. (2016). Impact of changes in land use, species and elevation on soil organic carbon and total nitrogen in Ethiopian Central High lands.Geoderma, $261,70-79$.

Thomas, G.W (1982) Exchangeable cations. In: Methods of Soil Analysis. (AL Page et al, eds) Agronomy 9; $154-$ 157 (Madison)

Tyagi, J. V., Qazi, N., Rai, S. P., \& Singh, M. P. (2013). Analysis of soil moisture variation by forest cover structure in lower western Himalayas, India. Journal of forestry research, 24(2), 317-324.

USDA-NRCS (2012).Natrual Resources Conservation Services: Soil Health. Retrieved June 23, 2016 from http://www.nrcs. usda.gov/wps/portal/nres/main/soils/health/.The Soil Renaissance accepted this definition in 2014

Walkley, A. and I.A. Black. 1934. An examination of the Degtjareff method for determining organiccarbon in soils: Effect of variations in digestion conditions and of inorganic soil constituents. Soil Sci. 63:251-263.

WMO. (1983). Guide to meteorological instruments and methods of observation. Secretariat of the World Meteorological Organization.

Woldemariam, T.G., 1998. Diversity of Woody Plants and Avifauna in a Dry Afromontane Forest: on the Central Plateau of Ethiopia MSc Thesis Swedish University of Agricultural Sciences, Skinnskatteberg, Sweden.

Zornoza, R., Acosta, J. A., Bastida, F., Domínguez, S. G., Toledo, D. M., \& Faz, A. (2015). Identification of sensitive indicators to assess the interrelationship between soil quality, management practices and human health.Soil,1(1), 173.

Doran, J.W., 1997. Soil quality and sustainability. In: Proceedings of the XXVI Brazilian Congress of Soil Science, Rio de Janeiro, Brazil, 20-26 July 1997.

Aerts, R. and Honnay, O., 2011. Forest restoration, biodiversity and ecosystem functioning. BMC Ecology 11:29.

Bremner, J.M. and Mulvaney, C.S. (1982) Nitrogen-Total. In: Methods of soil analysis. Part 2. Chemical and microbiological properties, Page, A.L., Miller, R.H. and Keeney, D.R. Eds., American Society of Agronomy, Soil Science Society of America, Madison, Wisconsin, 595-624.

Evans, R., Collins, A. L., Foster, I. D., Rickson, R. J., Anthony, S. G., Brewer, T., ... \& Zhang, Y. (2016). Extent, frequency and rate of water erosion of arable land in Britain-benefits and challenges for modelling. Soil Use and Management, 32, 149-161. 